Eldar VEREMCHUK, orcid.org/0000-0003-2926-2090 Candidate of Philological Sciences, Associate Professor at the Department of English Philology Zaporizhzhia National University (Zaporizhzhia, Ukraine) eldar.veremchuk@gmail.com

\title{
NATURE OF THE BASIC ENGLISH-LANGUAGE ETHICAL CATEGORIES: LINGUOCOGNITIVE APPROACH
}

The paper gives a throughout insight into the peculiarities of verbalization of ethical categories in the English language employing linguocognitive methodology. The aim of the paper is to distinguish principle classifiers of the basic ethical categories in the English language and to reveal their interconnection. The underlying principle of the research consists in the fact that language meaning has intrinsic connection with its form on the etymological layer. Thus, analyzing the inner form of language units can unravel the mechanisms of human perception of the world, which to a certain extend are based on the principle of metaphorical cross-domain mapping. The employed methods include: method of theoretical generalization, lexicographic analysis, etymological analysis, cognitive semantic analysis, conceptual analysis, method of cognitive interpretation. The difference between concept and category is highlighted. It consists in the fact that category makes up the kernel of the concept and is revealed in the conceptual classificational feature. Use of linguocognitive methodology together with etymological analysis allowed to establish primordial classifiers of the analyzed categories. The presented paper makes an attempt to explain the conceptual derivation of the ethical categories, which consists in metaphorical reinterpretation of the concrete concepts. It is stated that metaphor is a tool to cognize the objective reality based on ascribing features of the known portion of information to the one, which is in the focus of cognition on the basis of their resemblance. Based on the obtained lingual evidence we singled out the most prior classifier of the ethical categories, objectified by language means. Ultimately, the research reveals the interconnections among ethical categories based on the achieved cognitive data.

Key words: categorization, classifier, conceptual derivation, etymon, metaphor.

Ельдар ВЕРЕМЧУК, orcid.org/0000-0003-2926-2090 кандидат філологічних наук, дочент кафедри англійської філологї Запорізького начіонального університету (Запоріжжя, Україна) eldar.veremchuk@gmail.com

\section{ПРИРОДА БАЗОВИХ АНГЛОМОВНИХ ЕТИЧНИХ КАТЕГОРІЙ: ЛІНГВОКОГНІТИВНИЙ ПІДХІД}

Стаття висвітлює особливості вербалізаиії етичних категорій в англійській мові. Метою дослідження є встановлення основних класифікаторів базових англомовних етичних категорій та виявлення їх взаємозв'язку. Основоположний принции дослідження полягає в тому, щуо мовні значення мають внутрішній зв'язок зі своєю формою на етимологічному рівні. Таким чином, аналіз внутрішньої форми мовних одиниць розкриває механізми людського світосприйняття, які певною мірою базуються на приниипі метафоричного міжіменного перенесення. У статті були використані такі методи: метод теоретичного узагальнення, лексикографічний аналіз, етимологічний аналіз, когнітивно-семантичний аналіз, концептуальний аналіз, метод когнітивної інтерпретації. Окреслено різницю між концептом та категорією, яка полягає в тому, щзо категорія є стрижнем концепту і формує його концептуальні класифікаційні ознаки, які своєю чергою групують його диференційні риси. Класифікаційні риси виступають когнітивним «фільтром», завдяки якому уможливлюється категоризація дійсності. Використання лінгвокогнітивної методологї разом з етимологічним аналізом дало змогу встановити первинні класифікатори аналізованих категорій. Така праця робить спробу пояснити концептуальний розвиток абстрактних етичних категорій, щзо значною мірою грунтується на метафоричному переосмисленні конкретних концептів. Результати наукової праці доводять, щуо метафора - цее інструмент пізнання об 'єктивної дійсності, заснований на перенесенні ознак відомого об'єкта на той, щзо знаходиться в цчентрі пізнання на основі їх подібності. Було виділено первинні класифікатори аналізованих етичних категорій та встановлено їх взаємозв'язок та взаємозалежність. Найбільш первинними класифікаційними когнітивними ознаками є ознака "whole”, яка групує когнітивні диферениійні ознаки категорї GOOD, та “split”, яка виступає класифікатором етичної категорії EVIL.

Ключові слова: етимон, категоризація, класифікатор, концептуальна деривація, метафора. 
Introduction. Modern anthropologically biased paradigm, which has been established in contemporary science determines the dominant vector of research including philological sphere. "In the linguistics having the anthropocentric principle as its methodological basis two circles of problems come under spotlight: 1) determination of how the person influences the language and 2) determination of how the language influences the person, human thinking and culture" (Frumkina, 2008: 9).

This idea overlaps with the linguistic relativity hypothesis postulated by E. Sapir (Sapir, 1921) and B. L. Whorf (Whorf, 1956) in the first half of the $\mathrm{XX}^{\text {th }}$ century. Therefore, anthropocentric approach can be interpreted in the way that "transparency is everywhere" (Lee, 2016: 20), which means that the grammatical and semantic properties of a language reveal the way people perceive the world.

Human life involves two types of interactions: a) human / environment and b) human / other humans (society). Both are based on evaluation and as modern philosopher I. Iliin claims "Human world is the world of values that is crystallized out via the person's assessment of the Existence through binary parameters (oppositions) of real / desired, ontic / categorical, rational / irrational" (Iliin, 2005: 4). These values applied to assessment of human behavior constitute the scope of special categories - ethical categories.

It is worth mentioning that categorized portions of human knowledge often get into the focus of research and for now, there exists a number of works dedicated to such type of studies. It should be stated though that very often the object of research was narrowed to the analysis of verbal manifestation of the particular concept like JUSTICE (Vorcachev, 2011; Butova, 2013), DUTY (Mirzoeva, 2014), CONSCIENCE (Zaika, 2011), GOOD and EVIL (Mironova, 2011; Tseeva, 2012; Orlova 2016), HONOUR (on the material of Ukrainian (Dacissin, 2019), on the material of English (Mikolyuk, 2011), on the material of Indian culture (Qamar, 2015)). A. Ammer studied the peculiarities of proverbial verbalization of moral values on the material of Russian (Ammer, 2005). N. Stefanova gave a detailed analysis of the principles of classification of axiological dominants (Stefanova, 2018). Principles of categorization were profoundly analyzed by E. Rosch (Rosch, 1973).

The scope of the paper doesn't allow us to provide copious outlook of literature on the given topic but it should be mentioned that despite a big number of papers that analyze particular ethical concepts there are no scientific works, known to us, which research them in a bundle and reveal their interconnection and mutual dependence on the material of the English language, in particular.

Therefore, the aim of the paper is to distinguish principle classifiers of the basic ethical categories employing linguocognitive approach and to reveal their interconnection.

Considering the aim one should accomplish the following objectives:1) single out the main ethical categories objectified in the English language; 2) analyze the etymology of the lexemes, which verbalize them; 3) provide cognitive interpretation of the semantic development of the abovementioned lexemes; 4) find out the basic classifiers for each analyzed category; 5) distinguish the basic primordial dominant ethical category. The object of research are the basic ethical categories and the subject are their primary classifiers and mutual connections.

The methods used in this paper are as follows: theoretical generalization; lexicographic analysis, etymological analysis, cognitive semantic analysis, conceptual analysis, method of cognitive interpretation. The algorithm of the research contains the following steps: 1 . Defining the core ethical categories for the English world picture (theoretical generalization). 2. Creating the corpus of lexemes that verbalize the core ethical categories (method of lexicographic analysis). 3. Analysis of etymology of the verbalizers (etymological analysis). 4. Cognitive interpretation of the connections among the lexico-semantic variants of the lexemes (method of cognitive semantic analysis). 5. Establishing the most basic classificational features of the analyzed categories (conceptual analysis). 6 . Revealing the interconnection between the ethic categories on the basis of linguistic evidence (cognitive interpretation method). The application of cognitive analysis algorithms in this paper is based on the ideas of G. Lakoff (1983) Z. Popova, I. Sternin (2007), O. Kubryakova (2004).

\section{Results.}

\section{Theoretical prelude}

It is necessary to mention that the terms "category" and "concept" should be differentiated, though sometimes they are regarded as similar. Concept is the operational unit of memory, mental lexicon or to say metaphorically quantum of information (Kubryakova, 2004). In other words, it is a semantic bunch about some extralingual phenomena, formed in the process of cognition; mental representation of a class of objects or events. Category, on the contrary, is a collection of instances which are treated as if they are the same, based on the presence of some integral features.

A concept refers to all the knowledge that one has about a category as it has complex structure: sense, 
image (shared by the majority of speakers) and interpretational field (which may differ regarding the speakers' personal experience). Category is more universal that is shared by a bigger number of people and relates to the mechanisms of human cognition. Category is mental representation of the relations between different microconcepts based on the logical structure of the world. Therefore, category deals with hierarchical relationship between concepts.

The difference between concept and category is also apparent from the other perspective. Category is the content of human mechanisms of thinking, which are aimed at unification of the similar objects and differentiation the ones, which have different properties (process of categorization), while concept is the core operational unit, stored in memory and is formed as a result of conceptualization. Thus, categories are used for classifying objects in the process of cognition of something new, while concepts are used by human mind in the process of thinking (imagination, memorizing, remembering).

The borderline between category and concept is even more rigid when the content of concept is viewed as a combination of its sense, image and interpretational field (such conceptual structure is extensively described in (Popova, 2007)). Sense is part of content of concept, which contains the most salient cognitive features that differentiate it from other ones. Image contains all the cognitive traits, which are formed as a result of physical perception of the concept. Interpretation field includes all the features, which are actual for a limited number of speakers regarding their cultural background and experience.

Such macrostructure of concept taken together can be viewed as a bundle of cognitive traits, among which can be distinguished differential and classificational ones, the latter are also called classifiers (Lakoff, 1983). Both differential and classificational cognitive features belong to all the three abovementioned layers of concept: sense, image and interpretational field. Differential cognitive feature is a component of concept cognitive content, which is conceived by speakers, stored in their memory and is used to delineate concepts from each other. Under classifier we understand component of content of a concept, which reflects a certain parameter of categorization and unites cognitive differential traits. Classifiers carry out the function of cognitive filter, which enables human mind to consider certain things to be related to certain concept and excludes other objects from its extensional (the scope of extralingual phenomena, which are represented and objectified by the concept in human mind).

This process according to the prototype theory, elaborated by E. Rosch (Rosch, 1973) and later devel- oped by G. Lakoff, is carried out according to the idealized cognitive models, which are stored in human memory. Such process is called categorization, therefore from this perspective we posit that in the opposition 'category vs concept', category corresponds to the scope of classifiers, which are part of concept macrostructure (mostly sense and image components). The latter also includes differential cognitive features along with the classifiers. Therefore, the content of the concept is wider in semantic plane than the category because unlike category it also includes differential cognitive features.

\section{Primordial classifiers of ethical categories}

\subsection{Classifiers of the category GOOD}

The category GOOD is lexicalized by the lexeme good. It originated from Old English gōd, meaning "entire, complete"; "desirable", which in its turn comes from Proto-Germanic *gōda - "fitting, suitable, belonging together" - the Proto-Indo-European (PIE) verbal root which means "to unite, to be associated; suitable" (Etymology Dictionary). Thus, the derivational chain looks like that: "entire" - "belonging together; united" - "suitable" - "desirable". If to restore the reflection of this category in diachronic perspective, it becomes apparent that its primordial cognitive feature is "entire, united, whole". On psychological level something good is primarily associated with something whole, united, not split. In other words, something whole is positively assessed and is considered to be generally suitable. Given that humans are immanently oriented at preservation and sustainability of their lives, something suitable becomes the object of desire. Therefore, it can be inferred that the primordial classifier of the category GOOD is "being united". The etymologically derived classificational features of this category are "suitable", "desired".

\subsection{Classifiers of the category EVIL}

The category EVIL is verbalized by the word of the same name evil, which originated from Old English yfele "anything that causes injury, morally or physically" (Etymology Dictionary). Injury is regarded as something that splits the wholeness, therefore the etymology of this word proves that, EVIL has classifier - "something split or not united" - the opposite primordial feature to the category GOOD.

EVIL is also verbalized by the lexeme $b a d$, which went through the following stages of semantic derivation. Bad - "inadequate, unsatisfactory, worthless, wicked" originated from boeddel and its diminutive boedling "effeminate man, hermaphrodite, pederast", which probably are related to boedan "to defile" (Etymology Dictionary). From the cognitive perspective the analyzed category underwent the following conceptual changes: LSV "pederast" triggered two 
coherent lexico-semantic variants: "inadequate" and "wicked". The unnatural sexual relations for man were seen as inappropriate ones and automatically considered to be wicked and undesirable. As the idea of lingual semantic space development lies in the fact that people try to understand and nominate similar portions of information by the same or similar words (based on the metaphorical features of human mind to draw cross-domain mappings) the abovementioned meaning was generalized to the semanteme "undesirable and vicious". It can be concluded that the primordial classifier for the ethical category BAD is "physical defiling and unnatural homosexual relations". As it was argued concrete things underlie abstract ones. Therefore, concrete 'bad' later on was generalized to abstract category BAD.

One of the most salient examples of concrete bad for a human in terms of self-preservation is disease, which is a possible cause of death. This word originates from Old French desaise "lack, want" (Etymology Dictionary). On the conceptual level it can be interpreted in the following way: disease is the state when a person is lacking something, which means he is not "whole" as the whole entity is something that a priori cannot lack anything. So, disease is absence of unification, injury in its pure sense. Therefore, it can be inferred that the primordial classifier of the category BAD is proved to be "split; ununited".

Another verbalizer of the analyzed category is corruption, meaning "dishonest, illegal or immoral behavior, especially from someone with power". It comes from corrupcioun, "act of becoming putrid"; "dissolution, decay (of material things, especially dead bodies)" (Etymology Dictionary). Reinterpretation based on the conceptual metaphor aligned meaning "physical decay" with "spiritual decay". The abovementioned etymon derives from Latin corruptionem "spoiling, seducing" - noun of action from past-participle stem of corrumpere "to destroy; spoil", which is from a nasalized form of PIE * runp"to break" (Etymology Dictionary). The meanings "destroy, break", "decay" confirms our claim that category BAD is understood as something not whole, separated apart, broken, split and therefore the primordial classifiers are again "split", "ununited", "broken.

\subsection{Classifiers of the category JUSTICE}

The next category under analysis is JUSTICE, which is verbalized by the lexeme justice in the meaning "the quality of being right and deserving fair treatment", "moral soundness and conformity to truth" (Longman Dictionary). The verbalizer derives from Latin iustus "upright, righteous, equitable; in accordance with law, lawful; true, proper; perfect, complete" (Etymology Dictionary). We argue that the cognitive features "perfect" and "complete" underlie this moral category. Longman dictionary defines the word complete as "including all parts, details, facts etc and with nothing missing" (Longman Dictionary). Therefore, perfect is something good in its highest manifestation. In this way JUSTICE is something that is good in its sense and that doesn't lack anything. Therefore, it can be inferred that synonymic classifiers "wholeness", "single entity" or "being united", which underlie category GOOD also underlie category JUSTICE. The derived classificational feature of this category are "perfection", "completion".

\subsection{Classifiers of the category DUTY}

The category DUTY is verbalized by the lexeme duty, which means "the force of that, which is morally right" (Etymology Dictionary). It originates from Anglo-French duete, from Old French deu "due, owed; proper, just". French etymon is derived from vulgar Latin *debutus, from Latin debitus, past participle of debere "to owe", originally, "keep something away from someone", from de- "away" and habere "to have" (from PIE root *ghabh- "to give or receive") (Etymology Dictionary). We can infer that originally, to perform duty meant "to do something that you owe to somebody", which primarily meant "to do something that is kept away from somebody". Keeping something away means lack of something, in other words it is absence of wholeness, i.e. absence of good. Therefore, duty is understood as actions aimed at restoring this wholeness by ceasing "keeping something away". Thus, the primordial classifier of this category is "restoring wholeness", while the derived classifier is "not holding something good away from somebody".

\section{ITY}

2.5. Classifiers of the category RESPONSIBIL-

The category RESPONSIBILITY is verbalized by the lexeme responsibility, which means "something that is your job or duty to deal with" (Longman Dictionary). Semantic analysis proves that this category is connected with the category DUTY. The verbalizer comes from obsolete French responsible (13c., Modern French responsable, as if from Latin *responsabilis), from Latin respons-, past-participle stem of respondere "respond, answer to, promise in return", from re- "back" and spondere from sponsor "give assurance, promise solemnly" (Etymology Dictionary). Therefore, the primordial cognitive classificational feature is "promise of doing something right in return". As the etymological analysis shows, this category is connected with the category DUTY.

\subsection{Classifiers of the category CONSCIENCE}

The ethical category CONSCIENCE is verbalized by the word conscience, which originates from 
Old French conscience "conscience, innermost thoughts", which in its turn comes from Latin conscientia "a joint knowledge of something, a knowing of a thing together with another person". Latin etymon is an abstract noun of conscientem "to be (mutually) aware", which comes from con "with" and scire "to know" originally in the meaning "to separate one thing from another, to distinguish" (Etymology Dictionary). Etymological analysis of the etymon indicates that this category in its original sense is based on the ability to tell good from bad shared with other people or knowledge shared by the person and God. The primordial cognitive trait is "shared awareness of what is good".

\section{Interconnection of the classifiers of ethical} categories

As the etymological analysis revealed the most primordial ethical category is GOOD, which in its pure genuine sense has classifier "wholeness, entireness". The derived ethical category is JUSTICE, which has classifier "perfection, completion", which are originally based on the classifier of category GOOD - "wholeness". JUSTICE in its turn is highly related to DUTY, which literally denotes "to do justice" but in its genuine sense it means "doing something good". Thus, the primordial classifier is "restoring wholeness". The latter two categories are also closely connected with the category RESPONSIBILITY, the classifier of which is "doing something good in return". It differs from DUTY in the way that genuine classifier of RESPONSIBILITY is “restoring wholeness in return", while DUTY doesn't imply doing something good to pay back. Category CONSCIENCE is determined by the classifier "being mutually aware of something what is good", that is being aware of something that is whole. Therefore, category GOOD with its primordial classifier "whole" underlies all the aforementioned moral categories and is the most prior on the conceptual level.

Conclusions. The described above conceptual derivation proves that the basic feature of human cognition is metaphor, which is no longer seen as a stylistic trope but as a cognitive mechanism and the engine of human brain. Our research along with some recent ones, like (Kövecses, 2020) clearly proves that metaphor is a tool to cognize the objective reality based on ascribing features of the known portion of information to the one, which is in the focus of cognition on the basis of their resemblance. The analysis revealed that the most primordial classifier is "whole", which underlies all of the analyzed categories. It creates the dichotomic opposition to the classificational feature "split" that underlies the antagonistic category EVIL.

It should be mentioned that the scope of the paper allowed to research only a few categories through the analysis of their key verbalizers only, which still can yield plausible results considering that the key verbalizer contains sufficient amount of information for the researcher. Therefore, the perspective of further analysis lies in the deeper research of the abovementioned categories by investigating their other verbalizers alongside with the research of other ethical categories not mentioned in this paper, which constitute the English language linguoethical world picture.

\section{BIBLIOGRAPHY}

1. Аммер А. В. Вербализация фрагмента концептосферы «морально-этические ценности» в афоризмах и пословицах : автореф. дис. ... канд. филол. наук : 10.02.19. Воронеж, 2005. 24 с.

2. Бутова А. А., Крячко В. Б. Концепт «справедливость» в русской и английской лингвокультурах. Альманах современной науки и образования. 2013. № 7 (74). С. 23-25.

3. Дацишин Х. П. Вербальна репрезентація концепту «гідність» як об’єкта дії (за матеріалами українськомовного сегмента Інтернету). Теле- та радіожурналістика. 2019. Вип. 18. С. 147-155.

4. Фрумкина Р. М. Психолингвистика : учеб. пособие для студ. высш. учеб. заведений. Москва : Издательский центр «Академия», 2003. 320 c.

5. Ильин В. В. Аксиология. Москва : Изд-во МГУ, 2005. 216 с.

6. Kövecses Z. An extended view of conceptual metaphor theory. Review of Cognitive Linguistics. Cambridge, 2020. Is. 18 (1). 112-120.

7. Кубрякова Е. С. Об установках когнитивной науки и актуальных проблемах когнитивной лингвистики. Bonросы когнитивной лингвистики. 2004. № 1. С. 6-17.

8. Lakoff G. Classifiers as a Reflection of Mind: The Experiential, Imaginative, and Ecological Aspects. Oregon : University of Oregon, 1983. $22 \mathrm{c}$.

9. Lee V. About the subject of the anthropocentric paradigm in modern linguistics. GISAP: Philological Sciences. London, 2016. P. 19-20.

10. Миколюк О. А., Одарчук Н. А. Інтерпретація концепту “HONOUR” як морально-ціннісної категорії в аксіологічній системі християнства. Волинь, Волин. нац. ун-т ім. Лесі Українки. 2011. С. 112-115.

11. Миронова O. А. Реализация концептов GOOD и EVIL в английском языке на материале произведений авторов Высокого Фэнтези : автореф. дис. ... канд. филол. наук : 10.02.04. Санкт-Петербург, 2011. 19 с.

12. Мирзоева Л. Ю. К проблеме культурных импликаций в переводе: концепт «долг» в русском и в английском языке. GISAP : Philological sciences. 2014. № 3. C. 39-41. 
13. Орлова Т. Г., Никулина Е. Ф. Выражение добра и зла в английских и русских пословицах как отражение менталитета английского и русского народов. Вестник Российского университета дружбы народов. Теория языка. Семиотика. Семантика. 2016. С. 101-106.

14. Попова 3. Д., Стернин И. А. Когнитивная лингвистика : монография. Москва : Восток-Запад, 2007. 226 с.

15. Qamar A. H. "Laj", the concept for honour, shame and modesty of a woman in Indian popular culture. Lahore : UMT, 2015. 22 p.

16. Rosch E. H. Natural categories. Cognitive Psychology. Amsterdam, 1973. Is. 3. P. 328-350.

17. SAPIR E. Language: An Introduction to the Study of Speech. California : Harcourt Brace Jovanovich, 1921. 258 p.

18. Цеева 3. А. Концепты «Добро», «Зло» как ценности, отраженные в нормах поведения адыгов и британцев. Теория и практика общественного развития. 2012. № 4. С. 399-401.

19. Воркачев С. Г. Справедливость в английской лексикографии: имя концепта. Актуальные проблемы филологии и педагогической лингвистики. 2011. № 13. С. 35-41.

20. Whorf B. L., Carroll J. Language, Thought and Reality: Selected Writings by Whorf. Cambridge : MIT Press, 1956. $278 \mathrm{c}$.

21. Заика Т. В. Фразеологические средства репрезентации совестливости как фрагмента концепта совесть. Фундаментальные и прикладные исследования: проблемы и результатыл. 2014. № 10. С. 213-216.

22. Etymology dictionary. URL: https://www.etymonline.com

23. Longman Dictionary of Contemporary English. URL: http://www.ldoceonline.com//

\section{REFERENCES}

1. Ammer A. V. Verbalizacziya fragmenta konczeptosfery "moralno-eticheskie czennosti" v aforizmakh i posloviczakh: na materiale anglijskogo i russkogo yazykov [Verbalization of a fragment of the conceptosphere "moral and ethical values" in aphorisms and proverbs: on the material of English and Russian languages]. Voronezh, 2005 [in Russian].

2. Butova A. A., Kryachko V. B. Concept "spravedlivost" v russkoj i anglijskoj lingvokulturah. [Concept Justice in Russian and English linguocultures]. Almanac of modern science and education, 2013, Nr 7 (74), pp. $23-25$ [in Russian].

3. Dacissin K. P. Verbalna reprezentaciya konceptu «gidnist» yak ob'yekta diyi (za materialami ukrayinskomovnogo segmenta internetu) [Verbal representation of the concept of "dignity" as the object of actions (on the materials of the Ukrainian segment of the Internet)]. Tele- ta radiozhurnalistika, 2019. V. 18, pp. 147-155 [in Ukrainian].

4. Frumkina R. M. Psikholingvistika. [Psycholinguistics]. Moscow: Publishing center "Akademiya” [in Russian].

5. Iliin V. V. Aksiologiya [Axiology]. Moscow: Izd-vo MGU [in Russian].

6. Kövecses Z. An extended view of conceptual metaphor theory. Review of Cognitive Linguistics, 2020, Is. 18 (1), pp. 112-120. DOI: https://doi.org/10.1075/rcl.00053.kov

7. Kubryakova E. S. Ob ustanovkah kognitivnoj nauki i aktualnyh problemah kognitivnoj lingvistiki. [On the Precepts of Cognitive Science and Actual Problems of Cognitive Linguistics]. Cognitive linguistics issues, 2004, Nr 1, pp. 6-17. [in Russian].

8. Lakoff G. Classifiers as a Reflection of Mind: The Experiential, Imaginative, and Ecological Aspects. Oregon: University of Oregon. URL: https://escholarship.org/uc/item/65t327t6

9. Lee V. About the subject of the anthropocentric paradigm in modern linguistics. GISAP: Philological Sciences, 2016, pp. 19-20. DOI: 10.18007/gisap:ps.v0i11.1485.

10. Mikolyuk O. A., Odarchuk N. A. Interpretaciya konceptu "HONOUR" yak moralno-cinnisnoyi kategoriyi v aksiologichnij sistemi hristiyanstva. [Interpretation of the concept of "HONOUR" as a moral category in the axiological system of Christianity]. Naukovij visnik Volinskogo nacionalnogo universitetu imeni Lesi Ukrayinki, 2011, pp. 112-115 [in Ukrainian].

11. Mironova O. A. Realizaciya konceptov GOOD i EVIL v anglijskom yazyke na materiale proizvedenij avtorov Vysokogo Fentezi. [Realization of GOOD and EVIL concepts in English based on the works of authors of High Fantasy.] St. Petersburg [in Russian].

12. Mirzoeva L. Y. K probleme kulturnyh implikacij v perevode: koncept “dolg” v russkom i v anglijskom yazyke [To the problem of cultural implications in translation: the concept of "duty" in Russian and in English]. GISAP. Philological sciences, 2014, pp. 36-41 URL: http://gisap.eu/ru/node/34497 [in Russian].

13. Orlova T. G., Nikulina, E. F. Vyrazhenie dobra i zla v anglijskih i russkih poslovicah kak otrazhenie mentaliteta anglijskogo i russkogo narodov. [The expression of good and evil in English and Russian proverbs as a reflection of the mentality of the English and Russian peoples]. Vestnik RUDN, 2016, Nr 2, pp. 101-106. URL: https:/cyberleninka.ru/ article/n/vyrazhenie-dobra-i-zla-v-angliyskih-i-russkih-poslovitsah-kak-otrazhenie-mentaliteta-angliyskogo-i-russkogonarodov [in Russian].

14. Popova Z. D., Sternin I. A. Kognitivnaya lingvistika. [Cognitive linguistics]. Moscow: Vostok-Zapad [in Russian].

15. Qamar A. H. "LAJ", the concept for HONOUR, SHAME and MODESTY of a woman in Indian popular culture. Lahore: UMT. URL: https://www.researchgate.net/publication/326009196

16. Rosch E. Natural categories. Cognitive Psychology, 1973, Nr 4 (3), pp. 328-350.

17. Sapir E. Language: An Introduction to the Study of Speech. California : Harcourt Brace Jovanovich.

18. Tseeva Z. A. Koncepty «Dobro», «Zlo» kak cennosti, otrazhennye v normah povedeniya adygov i britancev. [The concepts of "Good", "Evil" as values reflected in the norms of behavior of Circassians and British]. Theory and practice of social development, 2012, $\mathrm{Nr} 4$, pp. 399-401 URL: https://cyberleninka.ru/article/n/kontsepty-dobro-zlo-kak-tsennostiotrazhennye-v-normah-povedeniya-adygov-i-britantsev [in Russian]. 
Veremchuk E. Nature of the basic English-language ethical categories: linguocognitive...

19. Vorcachev S. G. Spravedlivost v anglijskoj leksikografii: imya koncepta. [Justice in English Lexicography: The Name of the Concept]. Actual problems of philology and pedagogical linguistics, 2011, Nr 13, pp. 35-41. URL: https://cyberleninka.ru/article/n/spravedlivost-v-angliyskoy-leksikografii-imya-kontsepta [in Russian].

20. Whorf B. L., Carroll J. Language, Thought and Reality: Selected Writings by Whorf. Cambridge: MIT Press.

21. Zaika T. V. Frazeologicheskie sredstva reprezentacii koncepta "sovest" v sovremennom anglijskom yazyke. [Phraseological means of representing the concept of "conscience" in modern English]. Fundamental and applied research: problems and results, 2014, Nr 10, pp. 213-216 [in Russian].

22. Etymology Dictionary Online. URL: https://www.etymonline.com/

23. Longman Dictionary 26. URL: https://www.ldoceonline.com/ 